\title{
下顎運動のコンピュータ演算式
}

第 4 報 顆路と切歯指導板の調節值と対合歯の咬頭傾斜角の基準値から兒歯離開量を算出

$$
\text { 高山寿夫 }
$$

\section{Mathematical Expressions for Computing Mandibular Movement}

\author{
Part IV Equations for Calculating Amounts of Disocclusion on Articulator
}

\author{
Hisao Takayama
}

\begin{abstract}
Mathematical equations to calculate the amount of disocclusion on an articulator from adjustment values of the condylar guidance and anterior guide table and also cusp angles on the casts, were derived, based on the mathematical model of mandibular movement ${ }^{4,5}$. The equations derived can be used for analysing relations between the amounts of disocclusion, cusp angles on the casts and adjustment values on an articulator.
\end{abstract}

\section{はじめに}

第 $1 \sim 3$ 報 $^{1 \sim 3)}$ で, 下顎運動と咬合の関連を理論 と実験の両面から解析するために必要な一連のコ ンピュータ演算式の導出を行ってきた.

そのうち, 第 3 報引では著者らの導出したヒト の下䫇運動の数学モデル (一次近似式) ${ }^{4,5)}$ を基本 式とし, 生体の顆路と切歯路と対合歯の咬頭傾斜 角を既知として, 臼歯離開量を算出するためのコ ンピュータ演算式を導出した。しかし上下顎歯列 模型をマウントした咬合器上で, 咬合器の顆路と 金属性切歯指導板を調節して臼歯離開量を制御し ようとする場合には，第 3 報における切歯路を切 歯指導桿尖端の運動路に置き換えなければならな い. 切歯指導桿の尖端は切歯指導板にガイドされ るので, 切歯路の值の代わりに切歯指導板の調節 値を用いることになる。

国際デンタルアカデミー
一方, 第 2 報 ${ }^{2}$ で咬合器の顆路と切歯指導板の 調節值を既知として咬頭路を算出するためのコン ピュータ演算式を導出したが, 臼歯離開は咬頭路 と対合歯の咬頭傾斜との間にできるすき間である から, 臼歯離開量を算出するには第 3 報で行った ように, 臼歯離開量, 咬頭路傾斜度および咬頭傾 斜角の三者間の解析的関係にもとづいた演算を行 わなければならない.さらに実際問題としてこの 算出に必要となる咬頭路沿いの咬頭傾斜角のデー 夕は乏しいので, 咬頭傾斜角の代わりに臼歯離開 量の計測値（または標準値）を用い, 逆に咬頭傾 斜角を算出する手順を確立しておくことも有用で あろう。

本研究の目的は, 顆路と切歯指導板の調節値と 対合歯の咬頭傾斜角の基準值を既知として臼歯離 開量を算出するためのコンピュー夕演算手順を導 出するとともに, 顆路と切歯指導板の調節值と臼 歯離開量の計測值（または標準值）を既知として 咬頭傾斜角を算出する手順を導出することにあ る. 


\section{算出に用いる演算式}

上述した本研究の目的を達成するための算出に は, 第 2 報 ${ }^{2}$ およよ゙第 3 報3でそれぞれ導出した複 数の演算式の一部記号の表記と定義を変更したも のを用いる。

\section{1. 蝶番回転角の算出式}

表 1 に，第 2 報 ${ }^{2}$ で導出した“切歯指導板にガイ ドされた咬合器の上顎フレームの蝶番回転角の算 出式 (第 2 報; 表 2 )” を, 一部記号の定義と表記 を本研究の目的に合致するように変更した上で転 載した。前方運動では, 表 1 の（1）式に, 咬合 器の切歯指導桿尖端の 2 次元座標 $\left(\mathrm{A}_{\mathrm{g}}, \mathrm{C}_{\mathrm{g}}\right.$; 顆頭 間軸中点を原点とし, 前方および下方を正とす る), 矢状前方顆路傾斜度 $\Omega_{\mathrm{cp}}$, 切歯指導板の矢状 傾斜度 $\Omega_{\mathrm{gp}}$ および前方顆路長 $\Lambda_{\mathrm{cp}}$ を代入するこ とにより, 前方運動における上顎フレームの蝶番 回転角 $\Theta^{\mathrm{g}}{ }_{\mathrm{hp}}$ (開口方向を正とする) を算出するこ とができる。また側方運動では, 表 1 の（2）式 に, 咬合器の切歯指導桿尖端の 3 次元座標 $\left(\mathrm{A}_{\mathrm{g}}\right.$, $\mathrm{B}_{\mathrm{g}}=\mathrm{L}_{\mathrm{c}} / 2, \mathrm{C}_{\mathrm{g}}$; 作業側の顆頭中心を原点とし, 前 方, 舌側方および下方を正とする), 顆頭間距離 $\mathrm{L}_{\mathrm{c}}$, 矢状側方顆路傾斜度 $\Omega_{\mathrm{cl}}$, ベネット角 $\mathrm{B}_{\mathrm{e}}$, 切歯
指導板の矢状傾斜度 $\Omega_{\mathrm{gp}}$ および側翼角 $\mathrm{W}_{\mathrm{g} 1}$ およ び側方顆路長 $\Lambda_{\mathrm{cl}}$ を代入することにより，側方運 動における上顎フレームの蝶番回転角 $\Theta^{\mathrm{g}}{ }_{\mathrm{h} 1}$ (開口 方向を正とする）を算出することができる.

\section{2. 咬頭路の算出式}

表 2 に, 第 2 報 ${ }^{2)}$ で導出した“咬合器上の歯列模 型の咬頭路傾斜の算出式(第 2 報 ; 表 3 )”のうち, 咬頭の 3 次元変位に関する部分を一部記号の定義 と表記を本研究の目的に合致するように変更した 上で転載した，前方運動では，表 2 の（3）およ び (4) 式に, 咬合器の矢状前方顆路傾斜度 $\Omega_{\mathrm{cp}}$, 切歯点の 2 次元座標 $\left(\mathrm{A}_{\mathrm{i}}, \mathrm{C}_{\mathrm{i}}\right.$; 顆頭間軸中点を原 点とし, 前方および下方を正とする), 臼歯咬頭の 2 次元座標 $\left(\mathrm{a}_{\mathrm{m}}, \mathrm{c}_{\mathrm{m}}\right.$; 切歯点を原点とし, 後方およ び上方を正とする), 前方顆路長 $\Lambda_{\mathrm{cp}}$ および前方 蝶番回転角 $\Theta^{\mathrm{g}}{ }_{\mathrm{hp}}$ を代入することにより, 咬合器の 顆路と切歯指導板にガイドされた前方運動におけ る臼歯咬頭の前方および下方変位 $\left(\Delta \mathrm{X}_{\mathrm{mp}}^{\mathrm{g}}\right.$, $\left.\Delta Z^{\mathrm{g}}{ }_{\mathrm{mp}}\right)$ を算出することができる.側方運動の作業 側では表 2 の（5)〜（7）式に，また非作業側で は表 2 の（8）～(10) 式に, 咬合器の矢状側方顆 路傾斜度 $\Omega_{\mathrm{cl}}$, ベネット角 $\mathrm{B}_{\mathrm{e}}$, 切歯点の 3 次元座 標 $\left(A_{i}, B_{i}=L_{c} / 2, C_{i}\right.$; 作業側の顆頭中心を原点と

表 1 切歯指導板にガイドされた咬合器の上顎フレームの蝶番回転角の算出式

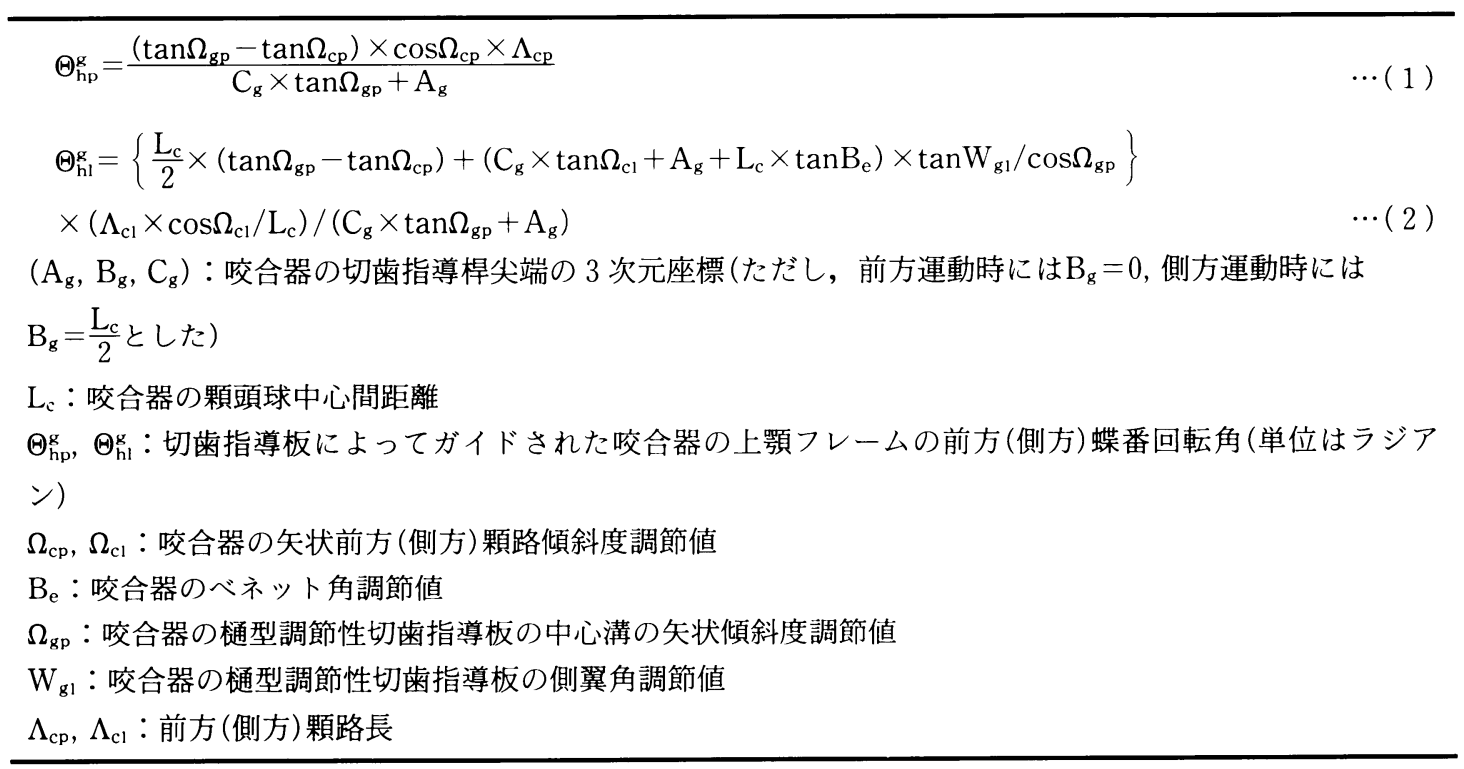


表 2 咬合器上の歯列模型の咬頭路の算出式

1) 前方運動

$$
\begin{aligned}
& \Delta \mathrm{X}_{\mathrm{mp}}^{\mathrm{g}}=\cos \Omega_{\mathrm{cp}} \times \Lambda_{\mathrm{cp}}-\left(\mathrm{C}_{\mathrm{i}}-\mathrm{c}_{\mathrm{m}}\right) \times \Theta_{\mathrm{hp}}^{\mathrm{g}} \\
& \Delta \mathrm{Z}_{\mathrm{mp}}^{\mathrm{g}}=\sin \Omega_{\mathrm{cp}} \times \Lambda_{\mathrm{cp}}+\left(\mathrm{A}_{\mathrm{i}}-\mathrm{a}_{\mathrm{m}}\right) \times \Theta_{\mathrm{hp}}^{\mathrm{g}}
\end{aligned}
$$

2 ）側方運動

(1) 作業側

$$
\begin{aligned}
& \Delta \mathrm{X}_{\mathrm{mw}}^{\mathrm{g}}\left(\frac{\mathrm{L}_{\mathrm{c}}}{2}-\mathrm{b}_{\mathrm{m}}\right) \times \delta_{1}-\left(\mathrm{C}_{\mathrm{i}}-\mathrm{c}_{\mathrm{m}}\right) \times \Theta_{\mathrm{hl}}^{\mathrm{g}} \\
& \Delta \mathrm{Y}_{\mathrm{mw}}^{\mathrm{g}}=\left\{\left(\mathrm{C}_{\mathrm{i}}-\mathrm{c}_{\mathrm{m}}\right) \times \tan \Omega_{\mathrm{cl}}+\left(\mathrm{A}_{\mathrm{l}}-\mathrm{a}_{\mathrm{m}}\right)+\mathrm{L}_{\mathrm{c}} \times \tan \mathrm{B}_{\mathrm{e}}\right\} \times\left(\Lambda_{\mathrm{cl}} \times \cos \Omega_{\mathrm{cl}} / \mathrm{L}_{\mathrm{c}}\right) \\
& \Delta \mathrm{Z}_{\mathrm{mw}}^{\mathrm{g}}=\left(\frac{\mathrm{L}_{\mathrm{c}}}{2}-\mathrm{b}_{\mathrm{m}}\right) \times \tan \Omega_{\mathrm{cl}}+\left(\mathrm{A}_{\mathrm{i}}-\mathrm{a}_{\mathrm{m}}\right) \times \Theta_{\mathrm{hl}}^{\mathrm{g}}
\end{aligned}
$$

(2) 非作業側

$$
\begin{aligned}
& \Delta \mathrm{X}_{\mathrm{mnw}}^{\mathrm{g}}=\left(\frac{\mathrm{L}_{\mathrm{c}}}{2}+\mathrm{b}_{\mathrm{m}}\right) \times \delta_{1}-\left(\mathrm{C}_{\mathrm{i}}-\mathrm{c}_{\mathrm{m}}\right) \times \Theta_{\mathrm{h} 1}^{\mathrm{g}} \\
& \Delta \mathrm{Y}_{\mathrm{mnw}}^{\mathrm{g}}=\left\{\left(\mathrm{C}_{\mathrm{i}}-\mathrm{c}_{\mathrm{m}}\right) \times \tan \Omega_{\mathrm{cl}}+\left(\mathrm{A}_{\mathrm{i}}-\mathrm{a}_{\mathrm{m}}\right)+\mathrm{L}_{\mathrm{c}} \times \tan \mathrm{B}_{\mathrm{e}}\right\} \times\left(\Lambda_{c l} \times \cos \Omega_{c l} / \mathrm{L}_{\mathrm{c}}\right) \\
& \Delta \mathrm{Z}_{\mathrm{mnw}}^{\mathrm{g}}=\left(\frac{\mathrm{L}_{\mathrm{c}}}{2}+\mathrm{b}_{\mathrm{m}}\right) \times\left(\tan \Omega_{\mathrm{cl}}\right) \times \delta_{1}+\left(\mathrm{A}_{\mathrm{i}}-\mathrm{a}_{\mathrm{m}}\right) \times \Theta_{\mathrm{hl}}^{\mathrm{g}}
\end{aligned}
$$

$\left(\Delta \mathrm{X}_{\mathrm{mp}}^{\mathrm{g}}, \Delta Z_{\mathrm{mp}}^{\mathrm{g}}\right)$ : 咬合器の顆路と切歯指導板にガイドされた前方運動における下顎臼歯咬頭の上顎に対する 2 次元変位.

$\left(\Delta \mathrm{X}_{\mathrm{mw}}^{\mathrm{g}}, \Delta \mathrm{Y}_{\mathrm{mw}}^{\mathrm{g}}, \Delta \mathrm{Z}_{\mathrm{mw}}^{\mathrm{g}}\right)$ : 咬合器の顆路と切歯指導板にガイドされた側方運動の作業側における下顎臼歯咬頭 の上䪽に対する 3 次元変位

$\left(\Delta \mathrm{X}_{\mathrm{mnw}}^{\mathrm{g}}, \Delta \mathrm{Y}_{\mathrm{mnw}}^{\mathrm{g}}, \Delta Z_{\mathrm{mnw}}^{\mathrm{g}}\right)$ : 咬合器の顆路と切歯指導板にガイドされた側方運動の非作業側における下顎臼歯 咬頭の上顎に対する 3 次元変位

$\left(\mathrm{A}_{1}, \mathrm{~B}_{1}, \mathrm{C}_{\mathrm{i}}\right)$ : 切歯点の 3 次元座標(ただし座標の原点は下顎固定とし, 前方および側方運動においてそれぞ れ顆頭間軸中点および作業側顆頭中心とした）

$\left(a_{m}, b_{m}, c_{m}\right)$ : 切歯点を原点とし, 後方, 煩側方, 上方を正とした臼歯咬頭の 3 次元座標

表 3 臼歯離開量の算出式

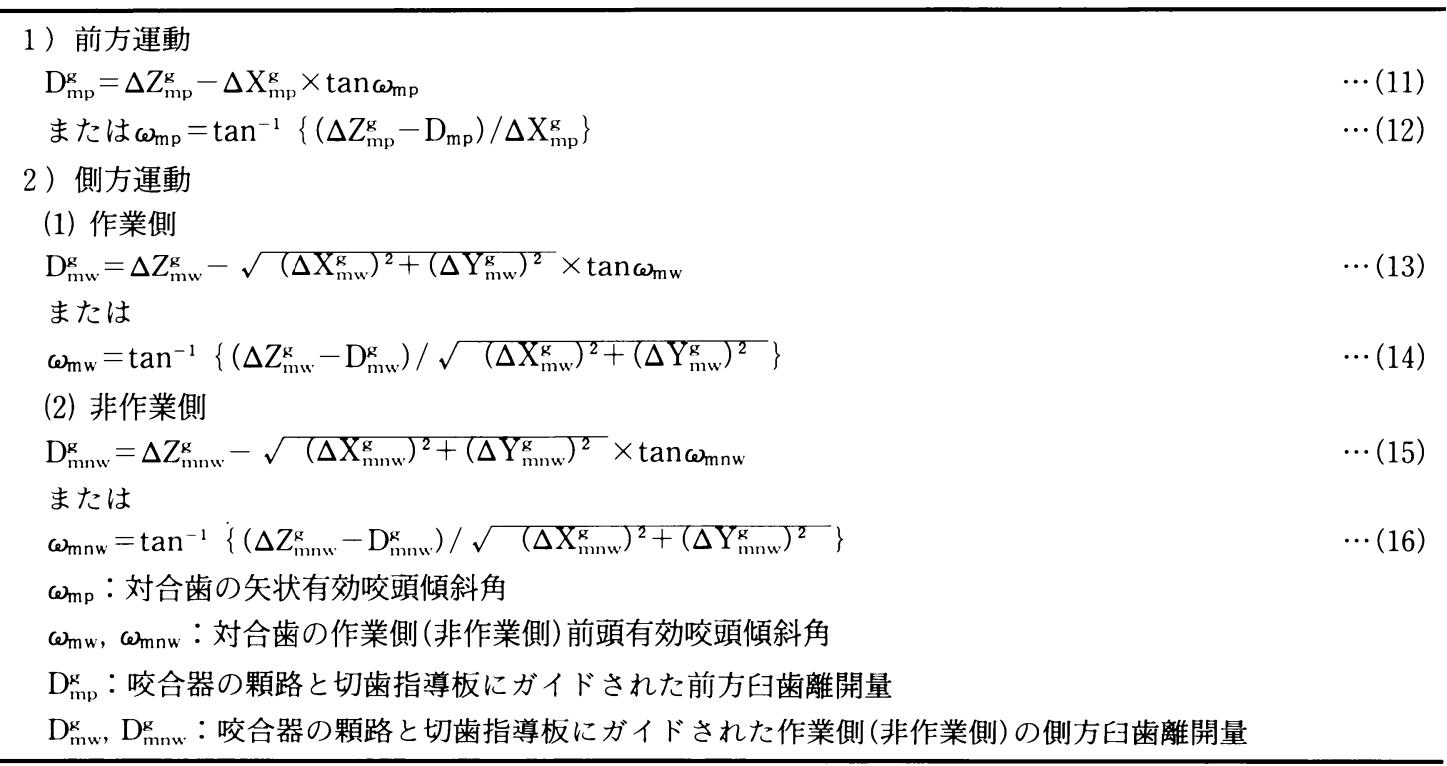


し, 前方, 舌側方および下方を正とする), 顆頭間 距離 $\mathrm{L}_{\mathrm{c}}$, 臼歯咬頭の 3 次元座標 $\left(\mathrm{a}_{\mathrm{m}}, \mathrm{b}_{\mathrm{m}}, \mathrm{c}_{\mathrm{m}}\right.$; 切歯 点を原点とし, 後方, 煩側方および上方を正とす る), 側方顆路長 $\Lambda_{\mathrm{cl}}$ および側方蝶番回転角 $\Theta^{\mathrm{g}}{ }_{\mathrm{h} 1}$ を代入することにより, 咬合器の顆路と切歯指導 板にガイドされた側方運動の作業側または非作業 側における臼歯咬頭の 3 次元変位（作業側では $\Delta \mathrm{X}_{\mathrm{mw}}^{\mathrm{g}}, \Delta \mathrm{Y}_{\mathrm{mw}}^{\mathrm{g}}, \Delta Z_{\mathrm{mw}}^{\mathrm{g}}$; 非作業側では $\Delta \mathrm{X}_{\mathrm{mnw}}^{\mathrm{g}}$, $\Delta \mathrm{Y}_{\mathrm{mnw}}^{\mathrm{g}}, \Delta Z_{\mathrm{mnw}}^{\mathrm{g}}$ ）を算出することができる.

\section{3. 臼歯離開量の算出式}

表 3 に, 第 3 報3)で導出した“臼歯離開量の算出 式”（第 3 報；表 2 ) を一部記号の定義と表記を本 研究の目的に合致するように変更した上で転載し た．前方運動では，表 3 の（11）式に，(前方運動 時の咬頭路に沿った）対合歯の矢状有効咬頭傾斜 角 $\omega_{\mathrm{mp}}$ および咬合器の顆路と切歯指導板にガイ ドされた前方運動における下顎臼歯咬頭の上顎に 対する 2 次元変位 $\left(\mathrm{X}_{\mathrm{mp}}^{\mathrm{g}}, Z_{\mathrm{mp}}^{\mathrm{g}}\right)$ を代入すること により, 咬合器の顆路と切歯指導板にガイドされ た前方臼歯離開量 $\mathrm{D}_{\mathrm{mp}}^{\mathrm{g}}$ を算出することができ

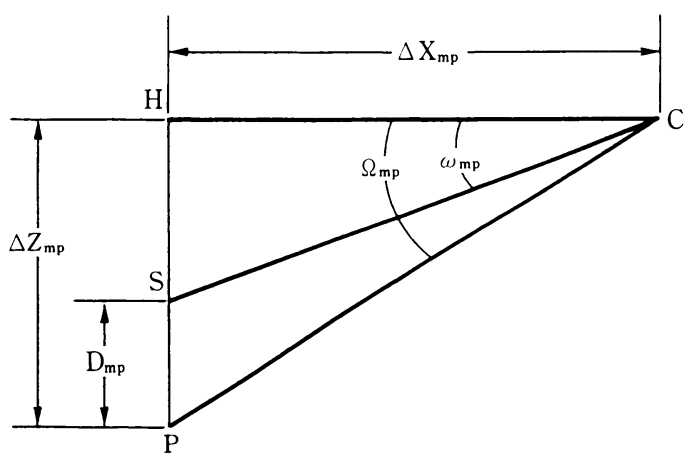

図 1 前方運動における臼歯離開量の算出原理図 (矢状面).

C：咬頭嵌合位における咬頭頂の対合歯咬合面と の接触点. $\Delta \mathrm{X}_{\mathrm{mp}}, \Delta Z_{\mathrm{mp}}$ : 前方運動における咬頭頂の 前方および下方変位, $\mathrm{C}-\mathrm{P}$ ：前方咬頭路, $\mathrm{C}-\mathrm{H}$ : 水 平基準面の矢状断面, $\angle \mathrm{PCH}$ : 矢状前方咬頭路傾斜 度 $\Omega_{\mathrm{mp}}, \mathrm{C}-\mathrm{S}$ ：対合歯の咬頭斜面の矢状断面, $\angle$ $\mathrm{SCH}$ : 対合歯の矢状前方有効咬頭傾斜角 $\omega_{\mathrm{mp}}$ 。 $\mathrm{D}_{\mathrm{mp}}$ ：前方運動時の臼歯離開量 (PS)（保母ら：咬合 学. クインテッセンス出版, 1995 より).
る.また側方運動の作業側では（13）式に対合歯 の（側方運動の作業側咬頭路に沿った）前頭有効 咬頭傾斜角 $\omega_{\mathrm{mw}}$ および咬合器の顆路と切歯指導 板にガイドされた作業側の下顎臼歯咬頭の上顎に 対する 3 次元変位 $\left(\Delta \mathrm{X}_{\mathrm{mw}}^{\mathrm{g}}, \Delta \mathrm{Y}_{\mathrm{mw}}^{\mathrm{g}}, \Delta \mathrm{Z}_{\mathrm{mw}}^{\mathrm{g}}\right)$ を, 非作業側では（15）式に（側方運動時の非作業側 咬頭路に沿った）対合歯の前頭有効咬頭傾斜角 $\omega_{\mathrm{mnw}}$ および下顎臼歯咬頭の 3 次元変位 $\left(\Delta \mathrm{X}^{\mathrm{g}}{ }_{\mathrm{mnw}}\right.$, $\left.\Delta \mathrm{Y}_{\mathrm{mnw}}^{\mathrm{g}}, \Delta Z^{\mathrm{g}}{ }_{\mathrm{mnw}}\right)$ を代入することにより，それぞ れ咬合器の顆路と切歯指導板にガイドされた作業 側および非作業側の側方臼歯離開量(作業側では， $\mathrm{D}^{\mathrm{g}}{ }_{\mathrm{mw}}$ ；非作業側では $\left.\mathrm{D}^{\mathrm{g}}{ }_{\mathrm{mnw}}\right)$ が算出できる。

\section{4. 臼歯離開量算出の原理図}

図 1 および図 2 に，第 3 報尚からそれぞれ前方

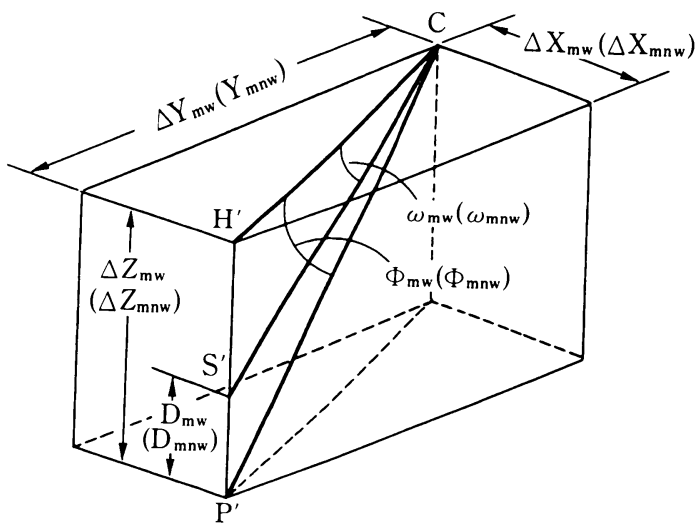

図 2 側方運動の作業側における歯離開量の算 出原理図（括弧内は非作業側における場合を示す）.

C：咬頭嵌合位における咬頭頂の対合歯咬合面と の接触点, $\Delta \mathrm{X}_{\mathrm{mw}}, \Delta \mathrm{Y}_{\mathrm{mw}}, \Delta Z_{\mathrm{mw}},\left(\Delta \mathrm{X}_{\mathrm{mnw}}, \Delta \mathrm{Y}_{\mathrm{mnw}}\right.$, $\Delta Z_{\mathrm{mnw}}$ ）：側方運動の作業側（非作業側）における前 方, 側方および下方変位, $\mathrm{C}-\mathrm{P}$ ：作業側(非作業側) における側方咬頭路， $\mathrm{C}-\mathrm{H}$ : 水平基準面の咬頭路 を含む垂直断面， $\angle \mathrm{PCH}$ ：作業側（非作業側）の前 頭咬頭路傾斜度 $\Phi_{\mathrm{mw}}\left(\Phi_{\mathrm{mnw}}\right), \mathrm{C}-\mathrm{S}$ : 対合歯の作業 側（非作業側）における咬頭斜面の咬頭路を含む垂 直断面, $\angle \mathrm{SCH}$ : 対合歯の前頭側方有効咬頭傾斜角 $\omega_{\mathrm{mw}}\left(\omega_{\mathrm{mnw}}\right), \mathrm{D}_{\mathrm{mw}}\left(\mathrm{D}_{\mathrm{mnw}}\right)$ ：作業側（非作業側）にお ける臼歯離開量 (PS), (保母ら, 咬合学.クインテッ センス出版, 1995 より). 
運動および側方運動における柬離開量算出の原 理図（第 3 報；図 1 および図 2 ）を転載した。図 3 はその模式図である。

\section{演算手順}

本研究で目的とした臼歯離開量の算出および咬 頭傾斜角の算出は, 前方運動および側方運動のそ れぞれにつき，前項に示した演算式を次のような 手順で順次組み合わせることによって達成でき る。

\section{1. 前方運動}

前方運動の場合には，（1）式の右辺を（3）お よび（4）式に代入し，次いで（3）および（4) 式の右辺を（11）式に代入するという手順でコン ピュータ演算プログラムを作成することにより， 咬合器の顆路調節值 $\left(\Omega_{\mathrm{cp}}, \Lambda_{\mathrm{cp}}\right)$, 切歯指導板調節 值 $\Omega_{\mathrm{gp}}$ および（前方運動の咬頭路に沿った）対合 歯の矢状有効咬頭傾斜角の基準值 $\omega_{m p}$ 等を与え て, 前方運動時の臼歯離開量 $\mathrm{D}_{\mathrm{mp}}^{\mathrm{g}}$ を算出するこ とができる.

もし甶歯離開量の計測值または標準值が既知で あって，対合歯の矢状有効咬頭傾斜角を求めたい 場合には上記の手順において（11）式の代わりに （12）式を用い，上記において矢状有効咬頭傾斜角 $\omega_{\mathrm{mp}}$ の代わりに前方臼歯離開量 $\mathrm{D}_{\mathrm{mp}}^{\mathrm{g}}$ を与えて, 矢状有効咬頭傾斜角 $\omega_{\mathrm{mp}}$ を算出すればよい.

\section{2. 側方運動}

側方運動の作業側では，（2）式の右辺を（5） および（7）式に代入し，次いで（5）（7）式 の右辺を（13）式に代入するという手順でコン ピュータ演算プログラムを作成することにより, 咬合器の顆路調節值 $\left(\Omega_{\mathrm{cl}}, \mathrm{B}_{\mathrm{e}}, \Lambda_{\mathrm{cl}}\right)$, 切歯指導板の 調節值 $\left(\Omega_{\mathrm{gp}}, \mathrm{W}_{\mathrm{g} 1}\right)$ および（側方運動の作業側咬 頭路に沿った）対合歯の作業側前頭有効咬頭傾斜 角 $\omega_{m w}$ 等を与えて, 側方運動時の作業側臼歯離開 量 $\mathrm{D}_{\mathrm{mw}}^{\mathrm{g}}$ を算出することができる.

同様に非作業側では，（2）式の右辺を（8）お よび（10）式に代入し，次いで（8）（10）式の 右辺を(15) 式に代入するという手順でコンピュー
夕演算プログラムを作成することにより, 咬合器 の顆路調節值 $\left(\Omega_{\mathrm{cl}}, \mathrm{B}_{\mathrm{e}}, \Lambda_{\mathrm{cl}}\right)$, 切歯指導板の調節值 $\left(\Omega_{\mathrm{gp}}, \mathrm{W}_{\mathrm{gl}}\right)$ および（側方運動の非作業側咬頭路に 沿った）対合歯の非作業側前頭有効咬頭傾斜角 的nnw 等を与えて, 側方運動時の非作業側臼歯離開 量 $\mathrm{D}^{\mathrm{g}}{ }_{\mathrm{mnw}}$ を算出することができる.

もし臼歯離開量の計測値または標準值が既知で あって，対合歯の有効咬頭傾斜角を求めたい場合 には上記の手順において（13）式または（15）の 代わりにそれぞれ（14）または（16）式を用い, 上記において有効咬頭傾斜角 $\omega_{\mathrm{m} w}$ または $\omega_{\mathrm{mnw}}$ の代わりに側方臼歯離開量 $\mathrm{D}^{\mathrm{g}}{ }_{\mathrm{mw}}$ または $\mathrm{D}^{\mathrm{g}}{ }_{\mathrm{mnw}}$ を 与えて, 前頭有効咬頭傾斜角 $\omega_{\mathrm{mw}}$ または $\omega_{\mathrm{mnw}}$ を 算出すればよい.

\section{考察}

以上のようにして, 本研究の目的とした演算式 が導出された。本研究で用いたヒトの下顎運動の 数学モデルは力学における Euler の定理を用い た一次近似式で, 近似を用いない一般式に比べ格 段の簡潔度を有しているが, 下顎運動の解析に応

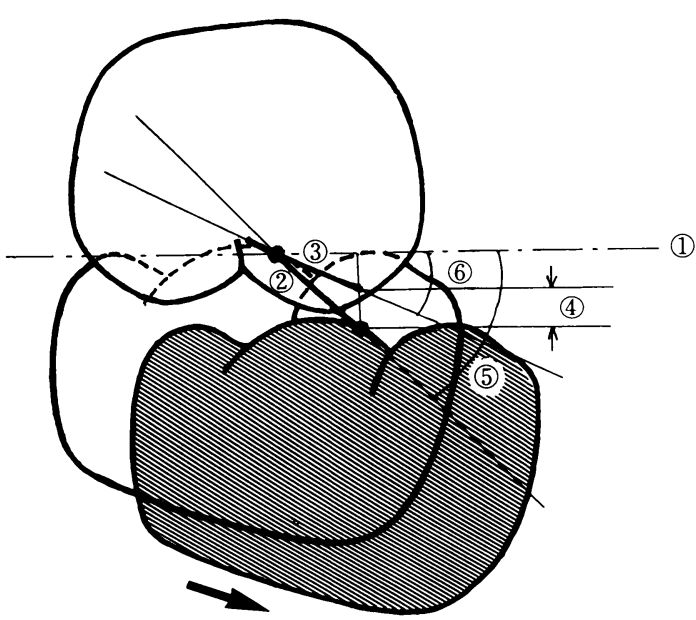

図 3 臼歯離開量算出原理の模式図.

(1) 水平基準面, (2)咬頭路, (3)咬頭斜面, (4)臼歯 離開量, (5)咬頭路傾斜度, (6)咬頭傾斜角. (保母須弥 也：ツインホビーによる新補経臨床術式. Dental Magazine 85, モリタ, 1995 より). 
用した場合，その近似誤差は変位において最大 33 $\mu \mathrm{m}$, 角度において最大 $0.8 \mathrm{deg}$ である ${ }^{4}$. したがっ て, 本研究で導出した演算式の精度は実用上十分 と考えられる。

図 4〜6 は第 3 報3で導出した “顆路と切歯路と 対合歯の咬頭傾斜の計測值から自歯離開量を算 出”する式の応用例で, 顆路と切歯路の值には標 準値を用いて有効咬頭傾斜角と臼歯離開量との関 係を求めたグラフである。図 4 は前方運動, 図 5 は側方運動の作業側, 図 6 は側方運動の非作業側 の場合を示している。これらの図は図中に示すよ うに，第一大臼歯および第二大臼歯における臼歯 離開量の計測データの平均值を与えてそれぞれの
有効咬頭傾斜角を推定するのに用いられた ${ }^{6)}$.

図 7〜9 は本研究で導出した“顆路と切歯指導板 と対合歯の基準值から印歯離開量を算出”する式 の応用例で, 図 7 は前方運動において顆路の值に は標準值を, 有効咬頭傾斜角には図 4 の推定結果 にもとづいて設定した基準值を用いて切歯指導板 の矢状傾斜度と臼歯離開量との関係を求めたグラ フである．図 8 および図 9 はそれぞれ，側方運動 の作業側および非作業側において顆路の值には標 準值を, 有効咬頭傾斜角には図 5 および図 6 の推 定結果にもとづいて設定した基準値を，さらに切 歯指導板の矢状傾斜度には図 7 を用いて求めた基 準値を用いて，それぞれ切歯指導板の側翼角と作

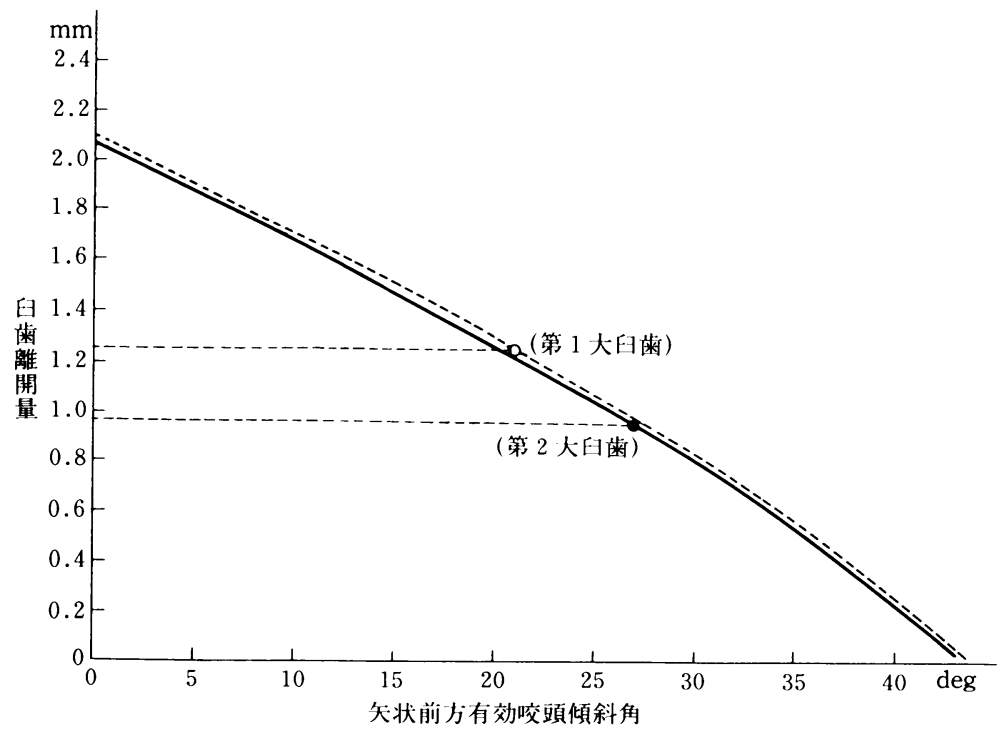

図 4 前方運動における臼歯離開量と第二大臼歯の矢状前方有効咬頭 傾斜角との関係を算出してプロットした結果 (実線)。標準値は矢状前方 顆路傾斜度を $40^{\circ}$, 矢状前方切歯路傾斜度を $45^{\circ}$ とした。第二大臼歯にお ける前方臼歯離開量の計測デー夕の平均値は $0.97 \mathrm{~mm}$ なので, この値を 繸軸にとって横一線に引いた直線とグラフとの交点を黒丸印で示す。こ の交点の横軸の值は約 $27^{\circ}$ と読み取れた。これが矢状前方有効咬頭傾斜 角の推定値である. 綎軸は前方臼歯離開量, 横軸は矢状前方有効咬頭傾 斜角. 破線と白丸印は第一大臼歯における結果. (保母ら：咬合学.クイ ンテッセンス出版, 1995 より) 
業側および非作業側の臼歯離開量との関係を求め たグラフである。これらの図は図中に示すように 臼歯離開量の標準値を与えて切歯指導板調節の際 の基準值を決定するのに用いられた。ちなみに， 図 8 および図 9 において臼歯離開量の基準值を作 業側で $0.5 \mathrm{~mm}$, 非作業側で $1.0 \mathrm{~mm}$ とし, そのい ずれにおいて求めた側翼角の調節値もほほ $20^{\circ}$ と なり同じ結果が得られたことは, 当然のことなが ら本研究で導出した演算式が実用式として有効で あり，かつ上記のようにして求めた有効咬頭傾斜
角の基準値と臼歯離開量の標準值が実用值として それぞれ正しいことを裏付けている.

以上の応用例から分かるように本研究で導出し た演算式は,第 $1 \sim 3$ 報で求めた演算式と合わせ, 下顎運動および咬合器のすべての誘導要素, 咬頭 形態並びに鼠歯離開量の相互関係の理論的解析, また一方から他方の推定, さらに実験データの一 貫性の確認等にきわめて有効なツールであるとい うことができるであろう.

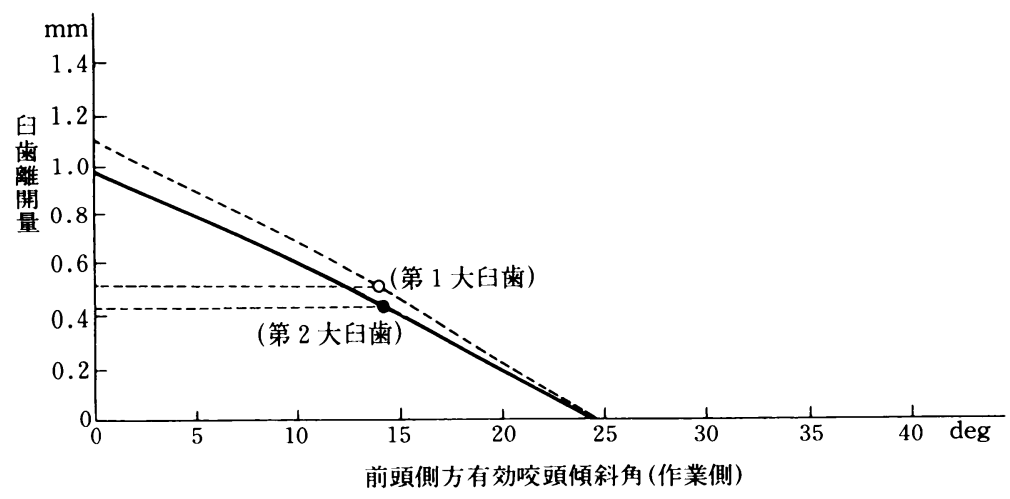

図 5 側方運動の作業側における臼歯離開量と第二大臼歯の前頭側方 有効咬頭傾斜角との関係を算出してプロットした結果(実線)。標準値は 矢状側方顆路傾斜度を $40^{\circ}$, ベネット角を $15^{\circ}$, 前頭側方切歯路傾斜度を $45^{\circ}$ とした。第二大臼歯における作業側の臼歯離開量の計測デー夕の平均 值は $0.43 \mathrm{~mm}$ なので, この値を縦軸にとって横一線に引いた直線とグラ フとの交点を黒丸印で示す。この交点の横軸の值は約 $14^{\circ}$ と読み取れた。 これが作業側の前頭側方有効咬頭傾斜角の推定值である。縦軸は作業側 臼歯離開量, 横軸は前頭側方有効咬頭斜角(作業側)。破線と白丸印は第 一大臼歯における結果.（保母ら：咬合学.クインテッセンス出版, 1995 より) 


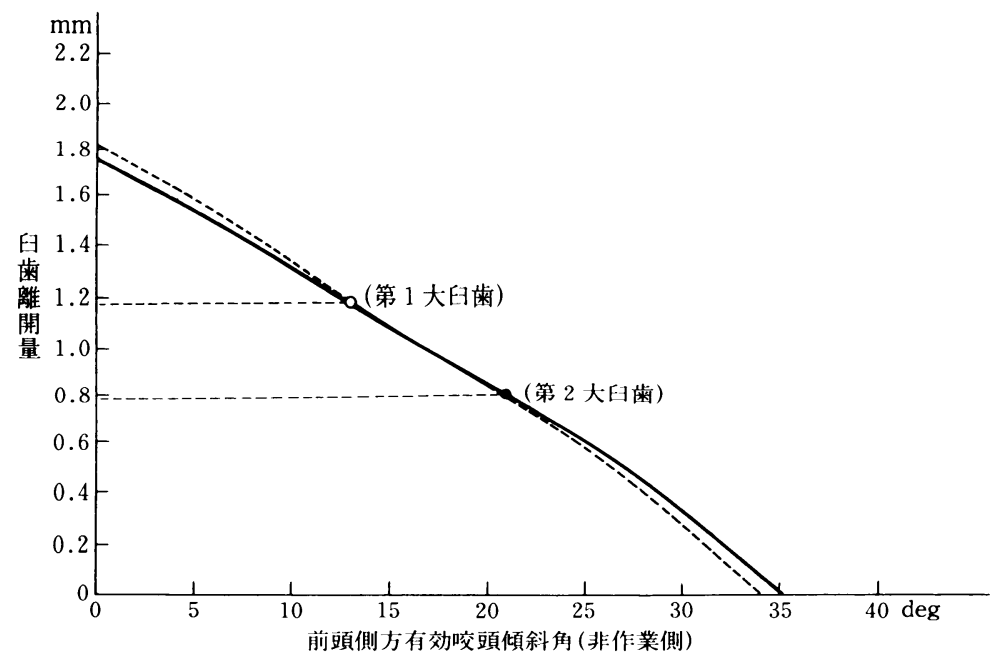

図 6 側方運動の非作業側における田歯離開量と第二大臼歯の前頭側 方有効咬頭傾斜角との関係を算出してプロットした結果(実線)。標準値 は矢状側方顆路傾斜度を $40^{\circ}$, ベネット角を $15^{\circ}$, 前頭側方切歯路傾斜度 を $45^{\circ}$ とした第二大臼歯における非作業側の臼歯離開量の計測デー夕 の平均値は $0.78 \mathrm{~mm}$ なので, この值を緃軸にとって横一線に引いた直線 とグラフとの交点を黒丸印で示す。この交点の横軸の值は約 $21^{\circ}$ と読み 取れた。これが非作業側の前頭側方有効咬頭傾斜角の推定値である. 縦 軸は非作業側臼歯離開量, 横軸は前頭側方有効咬頭傾斜角 (非作業側). 破線と白丸印は第一大臼歯における結果.（保母ら：咬合学.クインテッ センス出版, 1995 より)

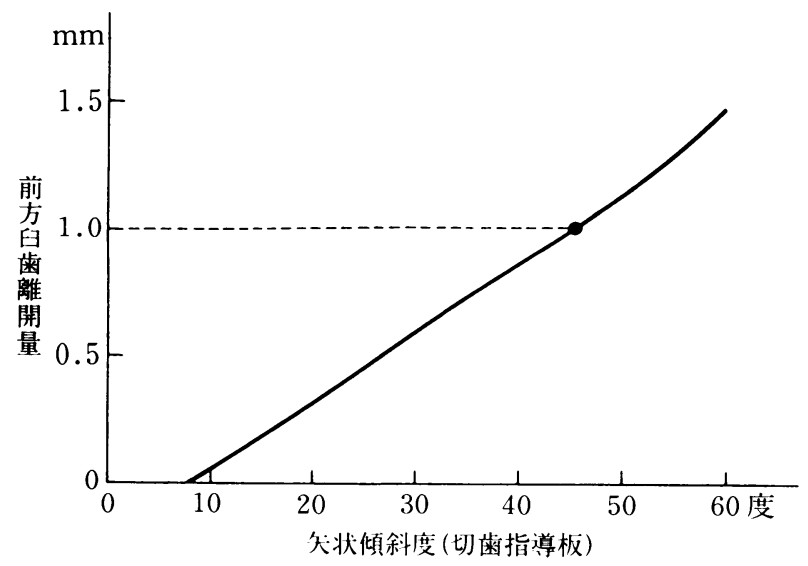

図 7 調節性の樋状切歯指導板の矢状傾斜度調節値と 前方臼歯離開量との関係を算出してプロットした結果. 矢状前方顆路傾斜角の標準值を $40^{\circ}$, 矢状前方有効咬頭 傾斜角の基準値を $25^{\circ}$ とした. 第二大臼歯における前方 臼歯離開量の標準值を $1.0 \mathrm{~mm}$ とし, この值を緹軸に とって横一線に引いた直線とグラフとの交点を黒丸印で 示す。この交点の横軸の值は約 $45^{\circ}$ と読み取れた.これが 切歯指導板の矢状傾斜度の調節值である. (保母ら：咬合 学. クインテッセンス出版, 1995 より) 


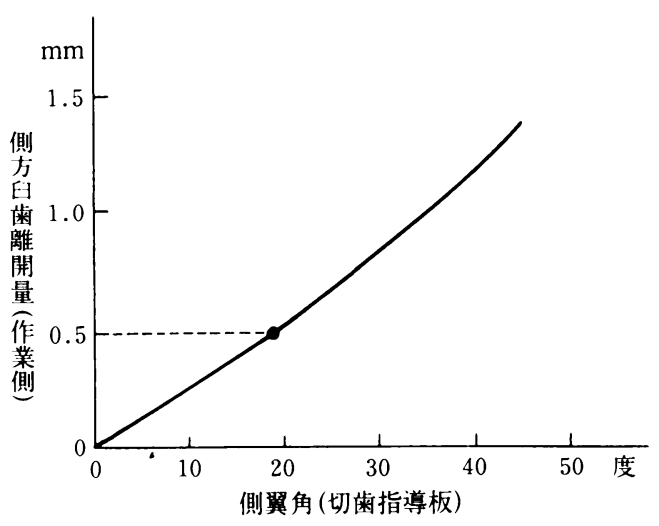

図 8 調節性の樋状切歯指導板の側翼角調節値と作業 側の側方臼歯離開量との関係を算出してプロットした結 果. 矢状側方顆路傾斜角の標準值を $40^{\circ}$, ベネット角を $15^{\circ}$ ，切歯指導板の矢状傾斜度を $45^{\circ}$ とし，作業側の前頭側 方有効咬頭傾斜角の基準值を $15^{\circ}$ とした. 第二大臼歯に おける作業側の側方臼歯離開量の標準值を $0.5 \mathrm{~mm}$ と し,この值を縦軸にとって横一線に引いた直線とグラフ との交点を黒丸印で示す。この交点の横軸の值は約 $20^{\circ}$ と読み取れた。これが切歯指導板の側翼角の調節值であ る. (保母ら：咬合学.クインテッセンス出版, 1995 より)

付記）：臼歯離開量の計測方法と計測結果について は前報フ 12)を, また臼歯離開量の解析結果については 既刊の拙著(6)参照されたい.

著者注）：前報 ${ }^{1 \sim 3} に$ に記載した演算式のうち, 第 1 報 ${ }^{1}$ に 1 力所, 第 2 報 $^{21}$ に 2 力所計 3 力所のミスプリン トが発見されているので,これらの演算式を利用され る際には著者宛お問い合わせいただきたく,お詫びと ともにお願いする次第である.

\section{結論}

下瀕運動の数学モデル4,5)を用い, 第 2 報2)で導出し た“切歯指導板にガイドされた咬合器の上顎フレーム の蝶番回転角の算出式” および “咬合器上の咬頭路の

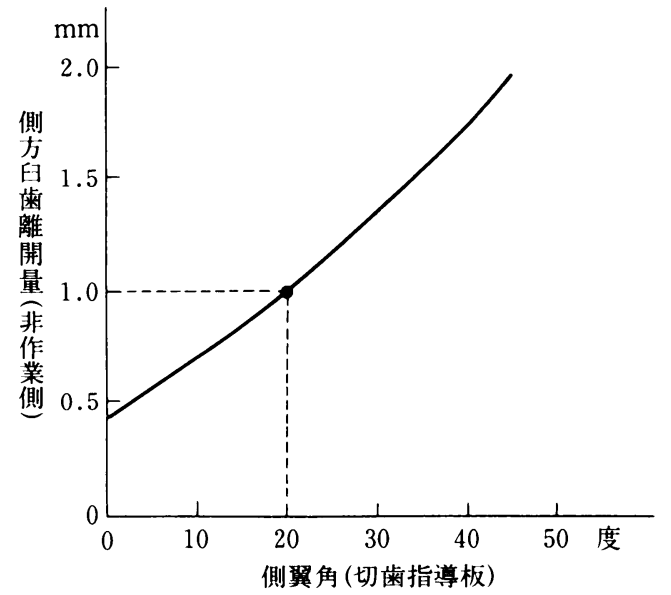

図 9 調節性の樋状切歯指導板の側翼角調節值と非作 業側の側方臼歯離開量との関係を算出してプロットした 結果. 矢状側方顆路傾斜角の標準值を $40^{\circ}$, ベネット角を $15^{\circ}$, 切歯指導板の矢状傾斜度を $45^{\circ}$ とし, 非作業側の前頭 側方有効咬頭傾斜角の基準值を $20^{\circ}$ とした. 第二大臼歯 における作業側の側方臼歯離開量の標準値を $1.0 \mathrm{~mm}$ と し,この値を縦軸にとって横一線に引いた直線とグラフ との交点を黒丸印で示す。この交点の横軸の值は約 $20^{\circ}$ と読み取れた。これが切歯指導板の側翼角の調節値で, 作業側と非作業側における算出結果はほほ等しい值と なった。(保母ら：咬合学.クインテッセンス出版, 1995 より)

算出式”に加え，第 3 報3で導出した“臼歯離開量の算 出式” の一部記号の定義と表記を本研究の目的に合致 するように変更し, 順次組み合わせることによって, 顆路と切歯指導板の調節值と対合歯の咬頭傾斜角の 基準值から兒歯離開量を算出する手順を導出した。本 研究で導出した演算式並びに手順は下額運動と臼歯 離開咬合の解析に有用であると考える。

\section{参考文献}

1）高山寿夫：下顎運動のコンピュータ演算式, 第 1 報 顆路と切歯路の計測値から咬頭路傾斜を 算出. 䫛咬合誌 $14: 84-87,1993$.

2）高山寿夫：下顎運動のコンピュータ演算式, 第 2 報 顆路と切䨑指導板の調節值から咬頭路傾 斜を算出. 影咬合誌 $14 ： 126-129,1993$. 
3）高山寿夫：下顎運動のコンピュータ演算式, 第 3 報顆路と切歯路と対合歯の咬頭傾斜の計測 值から兒歯離開量を算出. 顎咬合誌 15 ： 20〜23, 1994.

4）高山寿夫：臨床応用を目的としたヒトの下顎運 動の運動学的並びに実験的解析に関する研究. 東京大学学位審査論文 第 8203 号 : 1987.

5) Takayama, H. and Hobo, S.: The derivation of kinematic formulae for mandibular movement. Int J Prosthodont 2 : 285-295, 1989.

6) 保母須弥也 監著, 羽賀通夫, 高山寿夫 著: 咬 合学. クインテッセンス出版(株), 東京, 1995.

7）原元信貴, 高山寿夫, 保母須弥也：前方運動に おける臼歯離開量の計測，第 1 報 前歯「有り」 の場合. 顎咬合誌 $14: 4-6,1993$.

8）原元信貴, 高山寿夫, 保母須弥也：前方運動に おける臼歯離開量の計測, 第 2 報 前歯「無し」 の場合。顎咬合誌 $14: 16-19,1993$.
9）星野 元, 渡辺和夫, 高山寿夫, 保母須弥也： 非作業側における臼歯離開量の計測,第 1 報 犬 歯「有り」の場合. 顎咬合誌 $14: 41-44,1993$.

10）渡辺和夫, 星野 元, 高山寿夫, 保母須弥也： 非作業側における臼歯離開量の計測,第 2 報 犬 歯「無し」の場合. 顎咬合誌 $14: 77-80,1993$.

11）保母須弥也, 高山寿夫：犬歯誘導とグループ・ ファンクションの発現率に関する実験的解析. 顎咬合誌 $14: 70-73,1993$.

12）保母須弥也，高山寿夫：側方運動における臼歯 離開の実験的解析. 顎咬合誌 $14: 110-114$, 1993.

別刷請求先：高山寿夫

国際デンタルアカデミー 